\title{
Knowledge and misconceptions about sickle cell anemia and glucose-6-phosphate dehydrogenase deficiency among adult sickle cell anemia patients in al Qatif Area (eastern KSA)
}

Hussain A. Al-Suwaid, Magdy A. Darwish, Amr A. Sabra

Department of Family and Community Medicine, University of Dammam, Dammam, Saudi Arabia

Address for the Correspondence: Dr. Hussain A. Al-Suwaid, Department of Family and Community Medicine, University of Dammam, Dammam, Saudi Arabia. E-mail: Dr_4all@hotmail.com

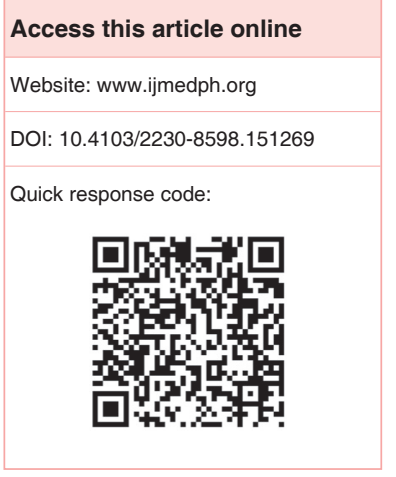

Introduction and Background: Sickle cell disease (SCD) is an extremely challenging disease of global concern. The highest prevalence of SCD in Saudi Arabia is in the Eastern province. Compared to all other areas of Saudi Arabia, Al-Qatif area has the highest gene frequencies for $\mathrm{HbS}$ and glucose-6-phosphate dehydrogenase (G-6-PD) deficiency genes. Objective: The objective of this study was to assess the knowledge and misconceptions about SCD of adults ( $\geq 18$ years) with sickle cell anemia in Al-Qatif area, Eastern Province, Saudi Arabia, and study factors that may affect them. Materials and Methods: A cross-sectional study using a selfadministered questionnaire was distributed to 320 patients aged $\geq 18$ years with sickle cell anemia, who attend the medical outpatient clinics in Qatif central hospital and primary care centers in the Qatif area, Eastern Province, Saudi Arabia. Result: A total of 300 participants completed their questionnaire. In general, $56.3 \%$ had poor knowledge of the disease. About $58.3 \%$ had good knowledge of the genetic transmission. The knowledge of $46.7 \%$ about the precipitating factors was poor. Moreover, $59.3 \%$ had poor knowledge of the diet of people with SCD and $81.3 \%$ had poor knowledge of the diet of people with G-6-PD deficiency. Conclusion: Our study revealed significant widespread misconceptions of patients with sickle cell anemia especially relating to their diet.

Key words: Knowledge, misconception, sickle cell anemia, G-6-PD deficiency

\section{INTRODUCTION}

Sickle cell disease (SCD) is an extremely challenging disease of global concern. ${ }^{[1]}$ Approximately, $5 \%$ of the world's population carries trait genes for hemoglobin disorders, mainly, sickle-cell disease and thalassemia. ${ }^{[12]}$

Sickle cell anemia is an autosomal recessive inherited disorder, characterized by the presence of HbS, a product of structural changes that occur in the $\beta$ chain of hemoglobulin, in which the glutamic acid is replaced by valin at the $6^{\text {th }}$ position. When deoxygenated, HbS polymerizes causing deformed red blood cells. This produces sickle cells, which are fragile, hemolyze, and block the small vessels. Patients usually present with pain "painful crisis" or chronic hemolytic anemia. ${ }^{[1,3,4]}$

The sickle cell gene was first recognized in Saudi Arabia in 1963 by Lehmann and co-workers in the eastern province of the country. ${ }^{[0,10]}$

Gelpi (1967) reported the presence of the HbS gene in the oasis population of Al-Qateef and Al-Hasa. ${ }^{[1]}$

The prevalence of SCD in Saudi Arabia varies significantly in different parts of the country, with the highest prevalence in the Eastern province followed by the South-western provinces. ${ }^{\left[{ }^{[3]}\right.}$

The reported prevalence for sickle-cell trait ranges from $2 \%$ to $27 \%$, with up to $2.6 \%$ in some areas with SCD ${ }^{[2]}$ Compared to all other areas of Saudi Arabia, Al-Qatif area has the highest gene frequencies for HbS and glucose-6-phosphate dehydrogenase (G-6-PD) deficiency genes. ${ }^{[15]}$ 
According to a study by Nasserullah et al. of the neonatal screening program homozygous SCD was detected in $2.35 \%$ and $1.08 \%$ in Qatif and $\mathrm{Al}$ Hasa, respectively. ${ }^{[8]}$ While G-6-PD deficiency revealed a high prevalence of $30.6 \%$ and $14.7 \%$ in Qatif and $\mathrm{Al} \mathrm{Hasa}$ respectively. ${ }^{[8]}$

Because of the global seriousness of this disorder, a large number of studies have been undertaken. Unfortunately, very few have addressed the issue of misconceptions about the disease particularly in Saudi Arabia.

The aim of this study was to assess the knowledge and misconceptions about SCD of adults ( $\geq 18$ years) with sickle cell anemia in the Qatif area, Eastern Province, Saudi Arabia, and study factors that may influence them.

\section{Specific objectives}

1. To assess knowledge and level of awareness of sickle cell adults ( $\geq 18$ years) about SCD.

2. To assess misconceptions about SCD in the above group.

3. To study the effects of sociodemographic data on the knowledge and misconceptions about SCD.

\section{MATERIALS AND METHODS}

A cross-sectional study using a self-administered questionnaire was implemented. Informed consent was obtained from all participants after they were given an explanation of the objectives of the study.

All questionnaires were anonymous, and the collected data were kept confidential and used only for the purpose of the study.

All necessary approvals from the Ministry of Health were obtained before the conduct of the study. Also, the study was approved by Ethical Committee of Postgraduate Saudi Board Program, Eastern Province.

All sickle cell anemia patients attending medical outpatient clinics in Qatif Central Hospital and the selected primary care centers in $\mathrm{Al}$ Qatif area who agreed to participate during the planned period of the study (from first of December 2013 to the end of January 2014) were enrolled in the study.

Patients aged $<18$ years, those in crisis, hospitalized or patients in the emergency room were excluded.

Primary health care centers were selected by systematic random sampling in which every third center from a list of 28 centers was chosen.

320 questionnaires were collected. All incomplete questionnaires were discarded, resulting in a total of 300 valid questionnaires.

162 completed questionnaires were collected from the hospital and 138 from 8 primary health care centers.

The questionnaire was divided into three sections:

- Section 1: Sociodemographic data and medical history

- Section 2: Questions to determine the history and severity of the disease.

- $\quad$ Section 3: Questions to assess knowledge and misconceptions about SCD through four-dimension.
The first about genetic transmission; the second about precipitating factors of sickle cell crisis; the third about sickle cell diet, and the $4^{\text {th }}$ about G-6-PD deficiency diet.

The questionnaire included a question that determined participants' sources of knowledge about sickle cell anemia.

The questionnaire was validated and modified in the light of the pilot study. The questionnaire was reviewed before and after the pilot study by 2 faculties and by 2 hematology consultants.

Reliability was calculated using Cronbach's Alpha and it was 0.875.

\section{Sample size}

The sample size was estimated according to the following equation: ${ }^{[16]}$

$N=\frac{\left(Z_{(1-\alpha / 2)}+Z_{(1-\beta)}\right)^{2} P(1-P)}{\mathrm{d}^{2}}$

N: Sample size

$Z$ : Reliability coefficient $(Z=1.96$ at $95 \%$ confidence interval);

Where $P=$ Proportion.

As there were no large previous studies on knowledge and misconceptions about SCD in KSA as far as the investigator could ascertain from the literature search, $P$ was considered to be $0.5(50 \%), d=0.08$, that is, absolute precision of $8 \%$ (i.e., a range of prevalence of $42-58 \%$ ) While type I error $(\alpha)$ was 0.05 and type II error $(\beta)$ was 0.2 (i.e., a power of $80 \%$ ).

The sample size was calculated as:

$N=\frac{\left([1.96+0.84]^{2} \times 0.5 \times 0.5\right)=1.96}{(0.08)^{2}=(0.0064)}=306$

\section{Data processing and analysis}

The data were coded, entered and analyzed in a personal computer using statistical package for social sciences (SPSS) software version 16 (SPSS Inc., Released 2007. SPSS for Windows, Chicago, USA). Data were presented using descriptive statistics in the form of frequencies and percentages for qualitative variables and mean and standard deviation (SD) for quantitative variables. Chi-square test was used as appropriate to determine the association.

A score of one was given for each correct answer and zero for wrong or don't know answers. The maximum score was 34 points. The mean of each dimension and the total score were then calculated. Any score above the mean was considered as good knowledge while a score below the mean was considered poor knowledge.

\section{RESULT}

Out of 320 questionnaires, 300 were valid, and representing 300 sickle cell anemia patients' responses. The mean age for the study population in years was $31.7 \pm 1.12 \mathrm{SD}$. 
Table 1 shows that almost half of the study population (54\%) were from the hospital setting while $46 \%$ were from the primary health care centers. Most of the patients (51\%) were in the age range of 15 $<30$ years and most were married (62\%). Educational level of $53.7 \%$ of the patients in this study was up to secondary school or diploma.

The income of $66.7 \%$ of the participants was $<5000$ Saudi Riyals (S.R), ( $\approx 1330 \$)$ and $49 \%$ of them were unemployed.

As shown in Table 2, (48.7\%) had SCD while (51.3\%) had the trait. The majority of the participants (65\%) had no G-6-PD deficiency.

Table 3 shows the distribution of patients with sickle cell anemia according to their level of knowledge about SCD.

Of the study population, (56.3\%) generally had poor knowledge. More than half of the participants (58.3\%) had good knowledge about genetic transmission, and (53.3\%) knew the precipitating factors of sickle cell crisis, yet they had poor knowledge of the diet of G-6-PD deficiency and SCD (81.3\% and 59.3\% respectively).

Figure 1 illustrates patients' level of knowledge about sickle cell anemia in general and for each section.

Table 4 shows the association between the levels of knowledge of sickle cell anemia patients with their sociodemographic characteristics. Most of the participants who had good knowledge $(65.6 \%)$ were from the hospital setting, and most of those with poor knowledge $(55 \%)$ were from the primary care setting $(P<0.01)$.

Those with good knowledge, $(41.2 \%)$ belonged to the age group of $15-<30$ years $(P<0.05), 60.3 \%$ of whom were female $(P<0.01), 71 \%$ were married $(P<0.05), 45.8 \%$ had secondary school education or a diploma $(P<0.05), 45.8 \%$ were not working $(P<0.05), 56.4 \%$ had an income of $<5000$ S.R $(P<0.001)$. The source of information for $63.4 \%$ was the hospital $(P<0.01)$ and $56.5 \%$ had SCD $(P<0.05)$.

Of those with poor knowledge, 56.2\% were male $(P<0.01)$, 58.6\% of them belonged to the age group of $15-<30$ years $(P<0.05)$, $59.8 \%$ had an educational level of up to secondary school or a diploma $(P<0.05), 51.5 \%$ were not working $(P<0.05), 74.6 \%$ had an income of $<5000$ S.R $(P<0.001)$, and $57.4 \%$ had the sickle cell trait $(P<0.05)$.

Correlation of level of knowledge with the number of children, source of information as relatives, friends, magazines, brochures, internet and primary health care centers, family history of sickle cell anemia, and G-6-PD deficiency was statistically not significant.

Table 5: Represents the results of the logistic regression analysis of the significant factors predictive of the level of knowledge about SCDs among studied sample. The following factors were found to be independently and significantly associated with a good level of knowledge; Patients attending the hospital, Female gender, higher income, and the hospital as a source of information.

\begin{tabular}{|c|c|}
\hline \multirow{2}{*}{$\begin{array}{l}\text { Sociodemographic } \\
\text { characteristics }\end{array}$} & Total $(n=300)$ \\
\hline & Number (\%) \\
\hline \multicolumn{2}{|l|}{ Study setting } \\
\hline Hospital & $162(54.0)$ \\
\hline Primary health care centers & $138(46.0)$ \\
\hline \multicolumn{2}{|l|}{ Age in years } \\
\hline $15-<30$ & $153(51.0)$ \\
\hline $30-<45$ & $104(34.7)$ \\
\hline $45-<60$ & $34(11.3)$ \\
\hline $60-75$ & $9(3.0)$ \\
\hline Mean age in years $\pm S D$ & $31.7 \pm 1.12$ \\
\hline \multicolumn{2}{|l|}{ Marital status } \\
\hline Single & $112(37.3)$ \\
\hline Married & $186(62.0)$ \\
\hline Divorced & $2(0.7)$ \\
\hline \multicolumn{2}{|l|}{ Educational level } \\
\hline Illiterate & $4(1.3)$ \\
\hline Read and write & $4(1.3)$ \\
\hline Primary school & $16(5.3)$ \\
\hline Intermediate school & $36(12.1)$ \\
\hline Secondary school or diploma & $161(53.7)$ \\
\hline University & $79(26.3)$ \\
\hline \multicolumn{2}{|l|}{ Occupation } \\
\hline Unemployed & $147(49.0)$ \\
\hline Manual worker & $28(9.3)$ \\
\hline Professional & $39(13.0)$ \\
\hline Others: student-retired-clerk & $86(28.7)$ \\
\hline \multicolumn{2}{|l|}{ Personal income in S.R } \\
\hline$<5000$ S.R & $200(66.7)$ \\
\hline $5000-<10,000$ S.R & $61(20.3)$ \\
\hline $10,000-<15,000$ S.R & $27(9.0)$ \\
\hline$\geq 15,000$ S.R & $12(4.0)$ \\
\hline
\end{tabular}

S.R = Saudi Riyals, SD = Standard deviation

Table 2: Medical history of blood disorders in the
study population

G-6-PD = Glucose-6-phosphate dehydrogenase

Table 6 shows sources of information about SCD among participants. The most frequent sources were the hospital $(52.3 \%)$, and the relatives $(49.3 \%)$.

\section{DISCUSSION}

In general, we found in our study that more than half of the respondents $(56.3 \%)$ had poor knowledge about sickle cell anemia. Most of these participants who had poor knowledge (55\%) were from the primary care setting $(P<0.01)$. 


\begin{tabular}{|c|c|c|c|}
\hline \multirow[t]{3}{*}{ Knowledge item } & \multicolumn{3}{|c|}{ Total $(n=300)$} \\
\hline & Yes & No & Don't know \\
\hline & Number (\%) & Number (\%) & Number (\%) \\
\hline \multicolumn{4}{|l|}{ A baby will be born with SCD when } \\
\hline Healthy person is married to someone with the trait* & $58(19.3)$ & $195(65.0)$ & $47(15.7)$ \\
\hline Healthy person married to someone with the disease & $100(33.3)$ & $149(49.7)$ & $51(17.0)$ \\
\hline Person with the trait married another with the trait & $228(76.0)$ & $36(12.0)$ & $36(12.0)$ \\
\hline Person with disease married to someone with the trait & $244(81.3)$ & $30(10.0)$ & $26(8.7)$ \\
\hline Healthy person married to another healthy person* & $33(11.0)$ & $234(78.0)$ & $33(11.0)$ \\
\hline \multicolumn{4}{|l|}{ Precipitating factors of sickle cell crisis } \\
\hline Fever & $186(62.0)$ & $44(14.7)$ & $70(23.3)$ \\
\hline Cold weather & $261(87.0)$ & $17(5.7)$ & $22(7.3)$ \\
\hline Hot weather & $158(52.6)$ & $65(21.7)$ & $77(25.7)$ \\
\hline Infection & $127(42.4)$ & $64(21.3)$ & $109(36.3)$ \\
\hline Psychological stressors & $195(65.0)$ & $38(12.7)$ & $67(22.3)$ \\
\hline Traveling at high altitudes & $163(54.4)$ & $31(10.3)$ & $106(35.3)$ \\
\hline Good hydration* & $42(14.0)$ & $200(66.7)$ & $58(19.3)$ \\
\hline Light exercises* & $42(14.0)$ & $200(66.7)$ & $58(19.3)$ \\
\hline Strenuous exercises & $213(71.0)$ & $40(13.3)$ & $47(15.7)$ \\
\hline \multicolumn{4}{|c|}{ Patients with SCD should abstain from the following foods to avoid a crisis } \\
\hline Fava beans* & $171(57.0)$ & $108(36.0)$ & $21(7.0)$ \\
\hline Lentils* & $145(48.3)$ & $127(42.3)$ & $28(9.4)$ \\
\hline Hummus or chickpeas* & $153(51.0)$ & $120(40.0)$ & $27(9.0)$ \\
\hline Kidney beans (Phaseolus) ${ }^{*}$ & $144(48.0)$ & $125(41.7)$ & $31(10.3)$ \\
\hline Vigna $(\text { Lobia })^{*}$ & $140(46.6)$ & $122(40.7)$ & $38(12.7)$ \\
\hline Nuts ${ }^{*}$ & $140(46.7)$ & $123(41.0)$ & $37(12.3)$ \\
\hline Peanuts* & $163(54.3)$ & $117(39.0)$ & $20(6.7)$ \\
\hline Qulabah (fava beans) ${ }^{*}$ & $152(50.6)$ & $119(39.7)$ & $29(9.7)$ \\
\hline Falafel made with Hummus or chickpeas* & $163(54.4)$ & $118(39.3)$ & $19(6.3)$ \\
\hline Falafel made with fava beans* & $169(56.4)$ & $106(35.3)$ & $25(8.3)$ \\
\hline \multicolumn{4}{|c|}{$\begin{array}{l}\text { Patients with G-6-PD deficiency should abstain from the following foods } \\
\text { to avoid a crisis }\end{array}$} \\
\hline Fava beans & $261(87.0)$ & $10(3.3)$ & $29(9.7)$ \\
\hline Lentils* & $225(75.0)$ & $39(13.0)$ & $36(12.0)$ \\
\hline Hummus or chickpeas* & $229(76.4$ & $37(12.3$ & $34(11.3$ \\
\hline Kidney beans (Phaseolus)* & $218(72.7)$ & $39(13.0)$ & $43(14.3)$ \\
\hline Vigna $(\text { Lobia })^{*}$ & $223(74.4)$ & $34(11.3)$ & $43(14.3)$ \\
\hline Nuts* & $215(71.7)$ & $46(15.3)$ & $39(13.0)$ \\
\hline Peanuts* & $238(79.4)$ & $25(8.3)$ & $37(12.3)$ \\
\hline Qulabah (fava beans) & $239(79.7)$ & $18(6.0)$ & $43(14.3)$ \\
\hline Falafel made with Hummus or chickpeas* & $230(76.7)$ & $31(10.3)$ & $39(13.0)$ \\
\hline Falafel made with fava beans & $253(84.3)$ & $14(4.7)$ & $33(11.0)$ \\
\hline
\end{tabular}

*Indicate the wrong statement. SCD = Sickle cell disease, G-6-PD = Glucose-6-phosphate dehydrogenase

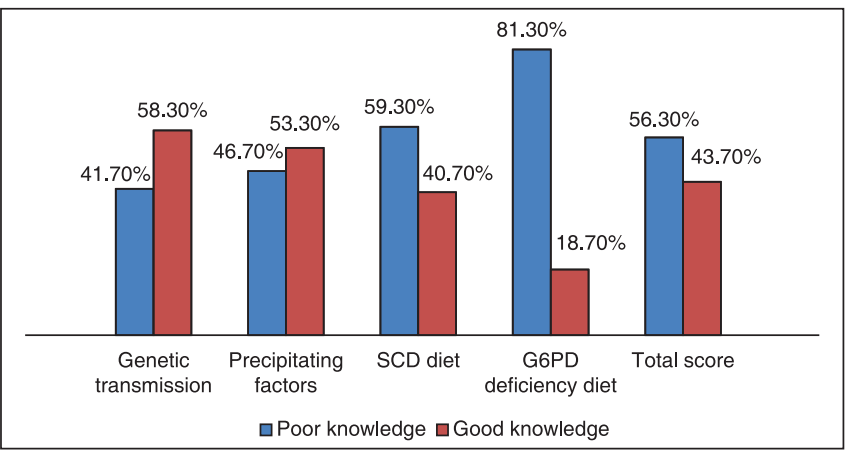

Figure 1: Distribution of patients according to their level of knowledge about sickle cell disease
Therefore, health education programs are needed, especially at the level of primary health care, to increase the level of awareness and to correct widespread misconceptions about sickle cell anemia in this vulnerable group of patients, particularly in view of the high prevalence of sickle cell anemia and G-6-PD deficiency in Qatif area.

This result was consistent with that in the study by Siddiqui et al., (2012) which revealed substantial knowledge gaps about sickle cells in surveyed people of reproductive age from the Dominican and African American communities in Northern Manhattan, despite the high prevalence of SCD in both groups. ${ }^{[6]}$ 


\begin{tabular}{|c|c|c|c|}
\hline \multirow[t]{3}{*}{ Variables } & \multicolumn{2}{|c|}{ Level of knowledge } & \multirow{3}{*}{$\begin{array}{c}\text { Test of } \\
\text { significance }(P)\end{array}$} \\
\hline & Poor $(n=169)$ & Good $(n=131)$ & \\
\hline & Number (\%) & Number (\%) & \\
\hline \multicolumn{4}{|l|}{ Study setting } \\
\hline Hospital & $76(45.0)$ & $86(65.6)$ & \multirow[t]{2}{*}{$X^{2}=24.3(P<0.01)=0.002$} \\
\hline Primary health care centers & $93(55.0)$ & $45(34.4)$ & \\
\hline \multicolumn{4}{|l|}{ Gender } \\
\hline Male & $95(56.2)$ & $52(39.7)$ & \multirow[t]{2}{*}{$X^{2}=8.1(P<0.01)=0.005$} \\
\hline Female & $74(43.8)$ & $79(60.3)$ & \\
\hline \multicolumn{4}{|l|}{ Age in years } \\
\hline $15-<30$ & $99(58.6)$ & $54(41.2)$ & \multirow[t]{4}{*}{$X^{2}=9.8(P<0.05)=0.021$} \\
\hline $30-<45$ & $52(30.7)$ & $52(39.7)$ & \\
\hline $45-<60$ & $14(8.3)$ & $20(15.3)$ & \\
\hline $60-75$ & $4(2.4)$ & $5(3.8)$ & \\
\hline \multicolumn{4}{|l|}{ Marital status } \\
\hline Single & $75(44.4)$ & $37(28.2)$ & \multirow[t]{3}{*}{$X^{2}=8.3(P<0.05)=0.016$} \\
\hline Married & $93(55.0)$ & $93(71.0)$ & \\
\hline Divorced & $1(0.6)$ & $1(0.8)$ & \\
\hline \multicolumn{4}{|l|}{ Educational level } \\
\hline Illiterate & $3(1.8)$ & $1(0.8)$ & \multirow[t]{6}{*}{$X^{2}=11.7(P<0.05)=0.039$} \\
\hline Read and write & $2(1.2)$ & $2(1.5)$ & \\
\hline Primary school & $9(5.3)$ & $7(5.3)$ & \\
\hline Intermediate school & $22(13.0)$ & $14(10.7)$ & \\
\hline Secondary/diploma & $101(59.8)$ & $60(45.8)$ & \\
\hline University & 32 (18.9) & $47(35.9)$ & \\
\hline \multicolumn{4}{|l|}{ Occupation } \\
\hline Unemployed & $87(51.5)$ & $60(45.8)$ & \multirow[t]{4}{*}{$X^{2}=13.2(P<0.05)=0.011$} \\
\hline Manual worker & $18(10.6)$ & $10(7.6)$ & \\
\hline Professional & $12(7.1)$ & $27(20.6)$ & \\
\hline Others & $52(30.8)$ & $34(26.0)$ & \\
\hline \multicolumn{4}{|l|}{ Personal income in S.R } \\
\hline$<5000$ S.R & $126(74.6)$ & $74(56.4)$ & \multirow[t]{4}{*}{$X^{2}=20.8(P<0.001)=0.000$} \\
\hline $5000-<10,000$ S.R & $33(19.5)$ & $28(21.4)$ & \\
\hline $10,000-<15,000$ S.R & $9(5.3)$ & $18(13.7)$ & \\
\hline$\geq 15,000$ S.R & $1(0.6)$ & $11(8.4)$ & \\
\hline \multicolumn{4}{|c|}{ Hospital as a source of information } \\
\hline Yes & $74(43.8)$ & $83(63.4)$ & \multirow[t]{2}{*}{$X^{2}=11.4(P<0.01)=0.001$} \\
\hline No & $95(56.2)$ & $48(36.6)$ & \\
\hline \multicolumn{4}{|c|}{ Classification of sickle cell anemia } \\
\hline Sickle cell disease & $72(42.6)$ & $74(56.5)$ & \multirow[t]{2}{*}{$X^{2}=5.7(P<0.05)=0.017$} \\
\hline Sickle cell trait & $97(57.4)$ & $57(43.5)$ & \\
\hline
\end{tabular}

It is also consistent with the study by Olakunle et al., which reported low comprehensive knowledge about SCD despite good awareness recorded among respondents. ${ }^{[14]}$

On the other hand, our results are different from those of a study in Bahrain by Al Arrayed and Al Hajeri, (2010) which showed that the level of knowledge about SCD among the public was good. ${ }^{[13]}$

They also differ from the study by Treadwell et al., in which over $68 \%$ responded correctly to knowledge questions about SCD. ${ }^{[7]}$

The major misconceptions found in our study related to the dietary factors that precipitate sickle cell crisis and G-6-PD hemolytic crisis.
On the diet of G-6-PD deficiency patients, $81.3 \%$ of the respondent generally exhibited poor knowledge.

Though most of the participants (87\%) were aware that beans could precipitate the hemolysis in patients with G-6-PD deficiency, they wrongly thought that other legumes (Lentils [87\%], Hummus [87.7\%], Kidney beans [87\%], Lobia [88.7\%], Nuts [84.7\%], Peanuts [91.7\%] and Falafel made with Hummus [89.7\%]) could also precipitate hemolysis.

We are encouraged by our results to focus in the health education program on foods that patients with G-6-PD deficiency may 


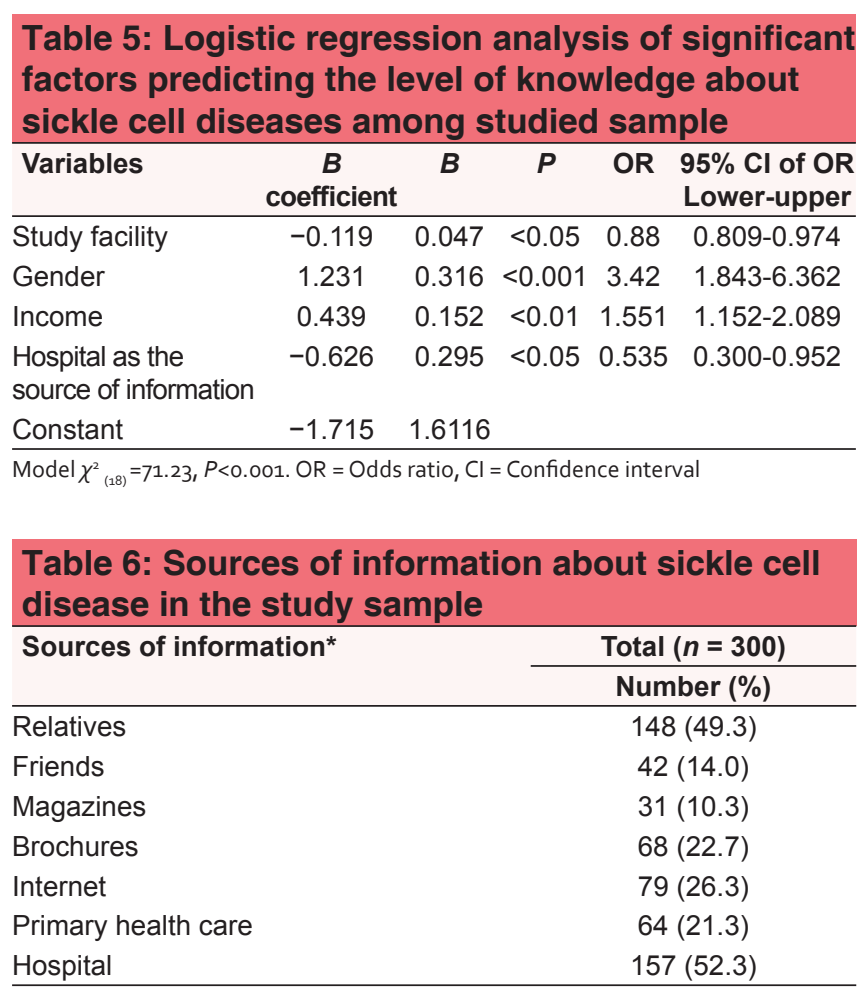

*Response categories were not mutually exclusive

or may not eat and those which are likely to precipitate the hemolysis.

In this study, $59.3 \%$ of the participants had poor knowledge of the diet restrictions of patients with sickle cell anemia.

The misconception that a sickle cell crisis could be precipitated by Fava beans was high among respondents (64\%).

This misconception extended to other legumes as well: (Lentils [57.7\%], Hummus [60\%], Kidney beans [58.3\%], Lobia [59.3\%], Nuts [59\%], Peanuts [61\%], Qulabah or minced beans [60.3\%] and Falafel made either with Hummus [60.7\%] or with Beans $[64.7 \%])$.

Hence, there is a need to explain to patients with sickle cell anemia that there is no evidence to support the view that the consumption of Fava beans and other legumes would trigger a crisis

Our result was consistent with the $\mathrm{Al}$ Arrayed and $\mathrm{Al}$ Hajeri study, (2011) that showed that almost two-third (58\%) of their study participants stated that certain types of food could trigger an attack. However, in fact, food items do not trigger SCD crises unless there is accompanying G-6-PD deficiency. In which case, only the consumption of fava beans would trigger an attack. ${ }^{[13]}$

Our result showed that the knowledge of respondents with SCD was better than those with sickle cell trait, which seemed logical. This was similar to the result of the study by Acharya et al., in which parents who had a child with SCD had better knowledge than those did not have a child with SCD $(78 \%$ vs. $58 \%, P=002) \cdot{ }^{[5]}$

The source of information in our study population was mainly the hospital $(52.3 \%)$ and relatives $(49.3 \%)$.

This suggested comprehensive educational program will focus and concentrate on the families of the patients, and in hospitals where these patients go for follow-up since they seem to be the main source of information as indicated by the study.

In a study by Acharya et al., the most common sources of information for parents with a child with SCD were pediatricians $(89 \%)$ and SCD clinic staff $(89 \%) \cdot{ }^{[5]}$

The study by Olakunle et al., showed that the major source of information included health professionals $(36.5 \%)$, the Internet $(11.1 \%)$, friends $(13.8 \%)$ and family $(18.2 \%) .{ }^{[14]}$

\section{CONCLUSION}

Our study revealed significant widespread misconceptions among patients with sickle cell anemia especially those related to diet.

Male participants had more misconceptions, and attendees of primary health care centers had more in comparison with those attending hospital. Participants with SCD were more knowledgeable than those with the sickle cell trait.

\section{REFERENCES}

1. Ameringer $S$, Smith WR. Emerging biobehavioral factors of fatigue in sickle cell disease. J Nurs Scholarsh 2011;43:22-9.

2. Jastaniah W. Epidemiology of sickle cell disease in Saudi Arabia. Ann Saudi Med 2011;31:289-93.

3. Al-Qurashi MM, El-Mouzan MI, Al-Herbish AS, Al-Salloum AA, AlOmar AA. The prevalence of sickle cell disease in Saudi children and adolescents. A community-based survey. Saudi Med J 2008;29:1480-3.

4. Longmore M, Wilkinson I, Turmezei T, Cheung C. Oxford Handbook of Clinical Medicine. $7^{\text {th }}$ ed. Oxford: Oxford University Press; 2007. p. 326.

5. Acharya K, Lang CW, Ross LF. A pilot study to explore knowledge, attitudes, and beliefs about sickle cell trait and disease. J Natl Med Assoc 2009;101:1163-72.

6. Siddiqui S, Schunk K, Batista M, Adames F, Ayala P, Stix B, et al. Awareness of sickle cell among people of reproductive age: Dominicans and African Americans in northern Manhattan. J Urban Health 2012;89:53-8.

7. Treadwell MJ, McClough L, Vichinsky E. Using qualitative and quantitative strategies to evaluate knowledge and perceptions about sickle cell disease and sickle cell trait. J Natl Med Assoc 2006;98:704-10.

8. Nasserullah Z, Al Jame A, Abu Srair H, Al Qatari G, Al Naim S, Al Aqib A, et al. Neonatal screening for sickle cell disease, glucose-6-phosphate dehydrogenase deficiency and a-thalassemia in Qatif and Al Hasa. Ann Saudi Med 1998;18:289-92.

9. Lehmann H, Maranjian G, Mourant AE. Distribution of sickle-cell hemoglobin in Saudi Arabia. Nature 1963;198:492-3.

10. Lehmann $\mathrm{H}$. Variations in human haemoglobin synthesis and factors governing their inheritance. Br Med Bull 1959;15:40-6.

11. Gelpi AP. Glucose-6-phosphate dehydrogenase deficiency, the sickling trait, and malaria in Saudi Arab children. J Pediatr 1967;71:138-46.

12. WHO.int. WHO sickle-cell disease and other haemoglobin disorders. 2013. Available from: http://www.who.int/mediacentre/factsheets/fs308/ en/. [Last cited on 2013 Sep 04]. 
13. Al Arrayed S, Al Hajeri A. Public awareness of sickle cell disease in Bahrain. Ann Saudi Med 2010;30:284-8.

14. Olakunle OS, Kenneth E, Olakekan AW, Adenike OB. Knowledge and attitude of secondary school students in Jos, Nigeria on sickle cell disease. Pan Afr Med J 2013;15:127.

15. El-Hazmi MA, Warsy AS. The frequency of glucose-6-phosphate dehydrogenase phenotypes and sickle cell genes in Al-Qatif oasis. Ann Saudi Med 1994;14:491-4.

16. Lwanga S, Lemeshow S. Sample Size Determination in Health Studies'A Practical Manual. $1^{\text {st }}$ ed. WHO; 1991. Available from: http://www.tbrieder. org/publications/books_english/lemeshow_samplesize.pdf. [Last cited on 2013 Feb 05].

How to cite this article: Al-Suwaid HA, Darwish MA, Sabra AA. Knowledge and misconceptions about sickle cell anemia and glucose-6-phosphate dehydrogenase deficiency among adult sickle cell anemia patients in al Qatif Area (eastern KSA). Int J Med Public Health 2015;5:86-92.

Source of Support: Nil, Conflict of Interest: None declared. 